\title{
Isolation and Characterization of Native Rhizobium Strains Nodulating Some Legumes Species in South Brazzaville in Republic of Congo
}

\section{Mabiala Shaloom Teresa ${ }^{1}$, Joseph Goma-Tchimbakala1,2*, Nzaou Stech Anomene Eckzechel ${ }^{1}$, Lebonguy Augustin Aimé ${ }^{1}$}

${ }^{1}$ Laboratoire de Microbiologie Appliquée et Biologie Moléculaire, Institut National de Recherche en Sciences Exactes et Naturelles (IRSEN), Brazzaville, République du Congo

${ }^{2}$ Ecole Nationale Supérieure d'Agronomie et de Foresterie, Brazzaville, Republique du Congo

Email: ^goma.tchimbakala@gmail.com

\begin{abstract}
How to cite this paper: Teresa, M.S., Goma-Tchimbakala, J., Eckzechel, N.S.A. and Aimé, L.A. (2021) Isolation and Characterization of Native Rhizobium Strains Nodulating Some Legumes Species in South Brazzaville in Republic of Congo. Advances in Bioscience and Biotechnology, 12, 10-30. https://doi.org/10.4236/abb.2021.121002
\end{abstract}

Received: November 12, 2020

Accepted: January 24, 2021

Published: January 27, 2021

Copyright $\odot 2021$ by author(s) and Scientific Research Publishing Inc. This work is licensed under the Creative Commons Attribution International License (CC BY 4.0).

http://creativecommons.org/licenses/by/4.0/

\begin{abstract}
Actually, in Republic of Congo, rhizobia have poorly phenotypically and biochemically characterized. This study aimed to characterize native rhizobia. Rhizobia strains were isolated using nodule roots collected on Milletia laurentii, Acacia spp., Albizia lebbeck, and Vigna unguiculata. The strains isolated were characterized microbiologically, biochemically, physiologically, and molecularly identified using $16 \mathrm{~S}$ rRNA method. The results reported in this study are only for six strains of all 77 isolated: RhA1, RhAc4, RhAc15, $\mathrm{RhAc13}, \mathrm{RhW} 1$, and RhV3. All native strains were positive to urease activity, negative to cellulase and pectinase activity except for one isolate that showed a positive cellulase activity. Moreover, isolates have grown at $12 \%$ of $\mathrm{NaCl}$. On different effects of temperatures, isolates were able to grow up to $44^{\circ} \mathrm{C}$ and showed good growth at $\mathrm{pH}$ from 7 to 9 and the ability to use ten different carbon hydrates sources. The strains were identified as Rhizobium tropici, Rhizobium sp., Mesorhizobium sp. Bradyrhizobium yuanmingense and Bradyrhizobium elkanii. The phylogenetically analysis of the 16S rRNA genes, using a clustering method, allowed us to have a history that is both ancient and stable of four clades among genes with similar patterns. Expanding our awareness of the new legume-rhizobia will be a valuable resource for incorporating an alternative nitrogen fixation approach to consolidate the growth of legumes. These germs can be used in Congolese agriculture to improve yield of crops.
\end{abstract}




\section{Keywords}

Rhizobia, Milletia laurentii, Acacia spp., Albizia lebbeck, Vigna unguiculata, $16 \mathrm{~S}$ rRNA Sequencing

\section{Introduction}

Nitrogen is an essential component of tissues and growth of plant. This component can be provided by industrial or biological sources. Nitrogenous fertilizers, the main sources of nitrogen for vegetable growth are industrially produced [1]. On the other hand, plant can get nitrogen through the mineral nutrition or by nitrogen-fixing that occurs across symbiosis between rhizobia and legumes. Cooperation between rhizobia and legumes has already been well studied in the background of a mutual nitrogen-fixing symbiosis [2] [3]. The fixation of symbiotic nitrogen $\left(\mathrm{N}_{2}\right)$ plays an important role in increasing plant biomass [4]. There is an increasing global need for enhancing food production to meet the needs of the fast-growing human population [5]. The conventional way of increasing agricultural yield through high inputs of chemical nitrogen, phosphate fertilizers and pesticides is not sustainable because of high costs and concerns about global warming, environmental pollution, and safety concerns. In this context, the use of natural soil microorganisms to increase the yield of food crops is an ecological, cost-effective and sustainable alternative tool to the use of chemical fertilizers and pesticides [6]. Several authors claimed that the family of Leguminoseae crops often associated with root nodulating bacteria improves nutritional stress by fixing atmospheric nitrogen [7] [8]. At the same time, legumes crops become able to access atmospheric di-nitrogen $\left(\mathrm{N}_{2}\right)$ by the symbiotic relationship with rhizobia that domicile within root nodules [9]. These symbioses are important interactions on the ecological level, influencing composition, diversity and succession of communities. They contribute to approximately 100 to 290 million tons of $\mathrm{N}$ per year to natural ecosystems and improving the growth of fodder plants and cultivated plants of agronomic importance worldwide. Also, bacteria have led to increased diversification of legumes thanks to nitrogen fixation [8]. The particular meaningful of plant-biotic reciprocal action is the mutualism between legume-rhizobia, within rhizobia fix atmospheric nitrogen to get carbon back supplied by the legume hosts, this mutualism adjusts to ensure accuracy regularly the nutrient cycles in natural ecosystems by making nitrogen available in agricultural environments [10]. Rising costs and the negative effects of pesticides and fertilizers on agricultural production necessitate addressing this problem through the use of organic products and natural crop protection options. The manipulation of plant growth-promoting (PGP) bacteria, for better plant health and betterment of soil, has become one of the captivating approaches for developing sustainable farming systems due to their particular respect for the environment, their production, and low cost and reduced con- 
sumption of non-renewable resources [11].

In Africa, a lot of studies showed that Legume-rhizobium symbiosis is one of the most successful models of co-evolution mutualisms between prokaryote and Eukaryote [12]-[17]. In Republic of Congo, studies on rhizobium-leguminous symbiosis had shown that inoculation of some leguminous plant with Bradyrhizobia strains enhanced the number of nodules per plant, total $\mathrm{N}$ in plant shoots, plant mass and yields of plants [18] [19] [20]. However, no study had been done on the biochemical and molecular characterization of rhizobia. Knowledge of rhizobia biodiversity and local populations is crucial to design the successful inoculation strategies because nitrogen fixation in agriculture can be enhanced by inoculating legumes with appropriate rhizobia [21] [22]. This study aimed to isolate and characterize the native rhizobia associated with food fodder and forest legumes. The goal is to create a symbiotic nitrogen-fixing germs bank in Republic of Congo. These germs could be used in the project of inoculating of leguminous in area with low yield crops. To carry out the study, the experiments were done on Vigna unguiculata, Milletia laurentii, Acacia spp. and Albizia lebeck.

\section{Material and Methods}

\subsection{Plant Collection}

Two sites were chosen for sampling of leguminous. The first site was situated at the Service National de Reboisement (SNR) of Brazzaville and the second site was at Mfilou in a farmer's field. Table 1 shows geographic locations of sites. Four leguminous plant species were collected in November 2018: Milletia laurentii, Acacia spp. and Albizia lebbeck at the SNR and Vigna unguiculata at MFILOU six weeks after seedling. After collecting leguminous plant species were immediately transported to the laboratory for analysis. At laboratory, experiments were carry out from November 2018 to December 2019 at Laboratoire de Microbiologie appliquée et de Biologie moléculaire of Institut National de Recherche en Sciences Exactes et Naturelles (IRSEN) for isolation and biochemical characterization of the strains and at the Biofidal laboratories (France) for molecular identification.

\subsection{Nodules Sampling and Rhizobia Isolation}

Nodules were carefully detached from the root system plant and washed several

Table 1. Geographic locations of sites.

\begin{tabular}{ccc}
\hline Sites & Geographic locations & Leguminous species \\
\hline SNR & Latitude: -4.2781929 & Milletia laurentii \\
& Longitude: 15.2515928 & Acacia spp. \\
Farmer's field & Albizia lebbeck \\
at MFILOU & Latitude: -4.2641 & Vigna unguiculata \\
\hline
\end{tabular}


times with sterile distilled water to remove soil particles. Surface of nodules was sterilized by immersion in 70\% ethanol for 5 minutes then in mercuric chloride solution $\left(\mathrm{HgCl}_{2}\right)$ for 2 minutes. After, they were washed ten times successively with sterilized distilled water. Nodules were cuted in two parts at the middle, the content of the nodule was picked up with a needle and streaked on a Petrie dish yeast extract mannitol agar (YMA) containing $25 \mathrm{mg} \cdot \mathrm{mL}^{-1}$ of Congo Red (CR) solution. YMA medium contain in $\mathrm{g} / \mathrm{L}$ : mannitol $10 \mathrm{~g}, \mathrm{~K}_{2} \mathrm{HPO}_{4} 0.5 \mathrm{~g}$, $\mathrm{MgSO}_{4}-7 \mathrm{H}_{2} \mathrm{O} 0.2 \mathrm{~g}, \mathrm{NaCl} 0.1 \mathrm{~g}$, and agar $15.0 \mathrm{~g}$. Plates were incubated at $28^{\circ} \mathrm{C}$ for 3 - 10 days. Single colonies were picked up, checked for purity by repeated streaking onto fresh YMA plates and then used for further analyses [23] [24] [25]. After isolation and purification, isolates were stored at $-80^{\circ} \mathrm{C}$ until their use.

\subsection{Biochemical Characterization}

Rhizobial strains obtained from all locations were purified and characterized. The characterization included Gram test with $\mathrm{KOH}$, catalase and oxidase test, macroscopic and microscopic observations. The growth on YMA containing bromothymol blue (YMA + BTB) was also observed.

\subsubsection{Rhizobium/Agrobacterium Differentiation Tests}

For this experiment, strains were grown on glucose-peptone agar (GPA) medium for 3 days at $28^{\circ} \mathrm{C}$, they were also tested for 3-ketolactose following recommendations of [26]. Rhizobia strains are not able to grow or have a poor growth on GPA and are negative for 3-ketolactose test. Only strains which were both negative for growth on GPA and 3-ketolactose test were selected for the following analysis.

\subsubsection{Growth Rate of Strains}

Flasks containing $50 \mathrm{~mL}$ of yeast extract mannitol (YM) medium were inoculated with a fresh inoculum incubated at $30^{\circ} \mathrm{C}$ on a rotary shaker for 15 days. The OD600 values were measured every 24 hours during growth phase. Experiments were performed in triplicates, and the average values were used to generate growth curves by Graph Pad Prism 7.0. The generation time was calculated using the following formula:

$$
\text { Generationtime }=\frac{\mathrm{T}_{2}-\mathrm{T}_{1}}{3,3\left(\log _{10} \mathrm{OD}_{2}-\log _{10} \mathrm{OD}_{1}\right)}
$$

where 3,3 is a constant; $T_{2}-T_{1}$ is the difference between two-time intervals at any two-point in $\log$ phase of growth curve; $\left(\log _{10} \mathrm{OD}_{2}-\log _{10} \mathrm{OD}_{1}\right)$ is the difference between two values of $\log _{10}$ of $\mathrm{OD}_{2}$ at $\mathrm{T}_{2}$ and $\mathrm{OD}_{1}$ at $\mathrm{T}_{1}$ [27].

\subsubsection{Urease, Cellulase and Pectinase Activity}

All native strains after being identified with classical methods were tested for urease, cellulase and pectinase activity [28]. For urease activity, strains were grown on YMA medium supplemented with $2 \%$ of urea and $0.012 \mathrm{~g}$ of phenol 
red. A positive activity is shown with the alcalinisation of medium which becomes pink [29]. Cellulase activity was carried out on a media containing $0.5 \%$ of CMC (Carboxy Methyl Cellulose). The cellulase activity were shown by pouring the petrie dishes with a $0.1 \%$ Congo red solution (w/v) then with a saline solution $(\mathrm{NaCl}$ at $1 \mathrm{M})$. A clear halo around colonies shows a positive activity. For pectinase activity, strains were grown on YMA medium supplemented with $0.5 \%$ of pectin. Pectinase activity was shown by pouring the petrie dishes with lugol, a clear or yellow halo around colonies show a positive activity. All experiments were incubated at $28^{\circ} \mathrm{C}$ during 5 days.

\subsubsection{Effect of $\mathrm{pH}$, Temperature and $\mathrm{NaCl}$ on the Growth}

Mid-exponential phase cultures of strains washed with phosphate buffer solution $\left(\mathrm{pH}\right.$ 7.0) were then diluted in YM medium and inoculated with $10^{7}$ cells per $\mathrm{ml}$ into tubes containing $10 \mathrm{~mL}$ of YM media for tolerance to $\mathrm{pH}$ values 4, 7, 8 and 9. In other hand, $10^{8}$ cells were inoculated in $10 \mathrm{ml}$ of YEM to test the effect of temperature or $\mathrm{NaCl}$. The temperature test stress was done with $28^{\circ} \mathrm{C}, 37^{\circ} \mathrm{C}$ and $44^{\circ} \mathrm{C}$ while for $\mathrm{NaCl}$ test medium was supplemented by $0 \%, 1 \%, 3 \%, 5 \%$ and $12 \% \mathrm{NaCl}$. All cultures were incubated at $30^{\circ} \mathrm{C}$ for 3 days. At the end of incubation, Optical Density was taken at $600 \mathrm{~nm}$.

\subsubsection{Use of Carbon Hydrates}

Mannitol, Glucose, Maltose, Fructose, Saccharose, Galactose, Lactose, Sorbitol, and Xylose were tested as carbon sources in the growth of strains. In YM medium, Mannitol as carbon sources was substituted by $1 \%$ of one of carbon hydrates cited above. Strains were incubated at $30^{\circ} \mathrm{C}$ for 3 days. At the end of incubation an Optical Density were taken at $600 \mathrm{~nm}$.

\subsubsection{Heavy Metals and Antibiotics Resistance}

The heavy metal resistance was tested by using wells method on trypton yeast extract (TY) solid medium containing in $\mathrm{g} / \mathrm{L}$ : trypton $5 \mathrm{~g}$, yeast extract $3 \mathrm{~g}, \mathrm{CaCl}_{2}$ $0.87 \mathrm{~g}$, agar $15 \mathrm{~g}$. Petrie dishes were incubated at $30^{\circ} \mathrm{C}$ for 24 to 48 hours. Mercury $(\mathrm{Hg})$, lead $(\mathrm{Pb})$, copper $(\mathrm{Cu})$, silver $(\mathrm{Ag})$, cobalt $(\mathrm{Co})$, zinc $(\mathrm{Zn})$, and nickel (Ni) with concentrations from 10 to $5000 \mu \mathrm{g} / \mathrm{mL}$ were tested. The diameter of inhibition zone (clear zone) was measured in centimeter $(\mathrm{cm})$ after 3 days of incubation, strains were considered as resistant when no inhibition were observed around wells.

Antibiogramme and his interpretation were done using the European Committee recommendations on Antimicrobial Susceptibility Testing (EUCAST, 2019). The antibiotics: Kanamycin $30 \mu \mathrm{g}$, Amikacin $30 \mu \mathrm{g}$, Oxacillin $1 \mu \mathrm{g}$, Erythromycin $15 \mu \mathrm{g}$, Streptomycin $10 \mu \mathrm{g}$, Gentamycin $10 \mu \mathrm{g}$, Chloramphenicol 30 $\mu \mathrm{g}$, Rafimpin $5 \mu \mathrm{g}$, Ampicillin $10 \mu \mathrm{g}$ and Amoxicilline $25 \mu \mathrm{g}$ were tested. Antibiotic discs were aseptically placed on Muller Hinton ( $\mathrm{MH})$ medium Petri dishes seeded with $100 \mu$ of fresh bacterial culture with optical density $\left(\mathrm{OD}_{625}\right)$ between 0.08 and 0.1 which corresponds to $10^{8}$ colony-forming unit (CFU), then incubated at $30^{\circ} \mathrm{C}$. The diameter of inhibition was measured in millimeters $(\mathrm{mm})$ af- 
ter 2 or 3 days of incubation.

\subsection{DNA Extraction and PCR Amplification of the 16S Ribosomal RNA Region}

DNA extraction and PCR amplification of the $16 \mathrm{~S}$ ribosomal RNA region was done by Biofidal laboratory (France). DNA was extracted with Omega BioteK Mag-Bind Universal Pathogen Kit following the manufacturer's instructions. Then, extracted DNA was quantifed with Quantus ${ }^{\text {Tix }}$ fluorimeter and Quantifluor Kit and migrated on a $1 \%$ agarose gel. The $16 \mathrm{~S}$ rRNA genes were Amplified with universal primers 27F (5'-AGAGTTTGATCMTGGCTCAG-3') and 1492R (5'-GGTTACCTTGTTACGACTT-3'). The PCR mix were obtained with $2 \mu \mathrm{L}$ DNA extract, $5 \mu \mathrm{L}$ of Mix HOTBIOAmp $5 \mathrm{X}$ à $12.5 \mathrm{mM} \mathrm{MgCl} 2,1.5 \mu \mathrm{L}$ of Enhancer 10X, $1 \mu \mathrm{L}$ of Primer 27F, $1 \mu \mathrm{L}$ Primer 1492R, $14.5 \mu \mathrm{L}$ of $\mathrm{ddH}_{2} \mathrm{O}$. The PCR mix were subjected to initial denaturation at $96^{\circ} \mathrm{C}$ for $12 \mathrm{~min}$ followed by 30 cycles of denaturation at $96^{\circ} \mathrm{C}$ for $20 \mathrm{~s}$, annealing at $56^{\circ} \mathrm{C}$ for the $20 \mathrm{~s}$, elongation at $72^{\circ} \mathrm{C}$ for $20 \mathrm{~s}$ and a final extension at $72^{\circ} \mathrm{C}$ for $5 \mathrm{~min}$. The quality of PCR products was checked on Qiaxcel, a single specific band size expected at around $1470 \mathrm{pb}$.

\subsection{Sequencing and Molecular Identification}

The primers 27F (5'-AGAGTTTGATCMTGGCTCAG-3'), 1492R

(5'-GGTTACCTTGTTACGACTT-3'), 805R

(5'-GACTACCAGGGTATCTAATCC-3') and 515F

(5'-TGYCAGCMGCCGCGGTA-3') were used for the sequencing of PCR products. Sequencing was done by Biofidal laboratories (France). PCR products were sequenced with BigDyeV3.1 Dye Terminator Kit-Thermo Fisher Scientific. The sequences were purified with BigDye Xterminator Kit before being analyzed on a 96 capillary sequencer ABI3730XL (Thermo Fisher Scientific). Alignment of sequences was done with CHROMAS Pro to create the complete counting of $16 \mathrm{~S}$ rRNA gene. Sequences were blasted on the NCBI GenBank database (https://www.ncbi.com/) for identification of strains. They were also submitted on NCBI GenBank database in order to obtain accession numbers.

\subsection{Phylogenetic Analysis of 16 S Nucleotides}

The $16 \mathrm{~S}$ rRNA nucleotides sequences with similarity $\geq 99 \%$ to the reference bacteria (Table 2) retrieved on NCBI database (https://www.ncbi.com/) were used for identification. Multiple sequence alignment of our six sequences was performed using DNAMAN, and a phylogenetic tree was created from the muscle aligned sequences using Molecular Evolutionary Genetics Analysis (MEGA X) software [30]. The 16S rRNA sequences for Agrobacterium K84, Rhizobium leguminisarum bv.viciae 3841, Rhizobium leguminisarum bv. trifolii WSM2304, Agrobacterium vitis S4, Agrobacterium tumefaciens str. C58 (Cereon), Mesorhizobium loti MAFF303099 and Bradyrhizobium japonicum USDA 110 derived from Microbes 
Table 2. Percentage of homology of strains and accession number.

\begin{tabular}{ccccc}
\hline Host plant & Strains & References strains & $\begin{array}{c}\text { Homology } \\
(\%)\end{array}$ & $\begin{array}{c}\text { Accession } \\
\text { number }\end{array}$ \\
\hline Albizia lebeck & RhA1 & Rhizobium tropici & $99.79 \%$ & MT657288 \\
& RhAc13 & Mesorhizobium sp. & $99.72 \%$ & MT657292 \\
Accacia spp & RhAc15 & Rhizobium sp. & $99.86 \%$ & MT657293 \\
& RhAc4 & Rhizobium tropici & $99.79 \%$ & MT657291 \\
Millettia laurentii & RhW1 & Bradyrhizobium elkanii & $99.64 \%$ & MT657298 \\
Vigna unguiculata & RhV3 & Bradyrhizobium & yuanmingense & MT657303 \\
& & &
\end{tabular}

online database (http://www.microbesonline.org/) were recovered from the selected genome and add as references in the tree for consensus sequences.

\section{Results}

\subsection{Isolation of Native Rhizobia from Legumes Species}

Atotal of 77 strains were obtained and divided as follows: 25 from Acacia spp, 15 from Millettia laurentii, 17 from Alibizia lebeck and 20 from Vigna unguiculata. Strains from Acacia spp. and Albizia lebeck appeared on the culture medium after 5 days whereas Vigna unguiculata strains grown on the medium appeared after 8 days and those of Millettia laurentii after 9 days. They were white or pink on $\mathrm{YMA}+\mathrm{CR}$, translucid or opaque. The strains were Gram-negative, Catalase and Oxidase positives. Microscopic observations revealed that strains were bacteria rod-shapped and motile. All Vigna unguiculata and Milletia laurentii strains were slow-growing bacteria. They took 7 to 9 days to appear on the YMA medium after isolation while Albizia lebeck strains were fast-growing bacteria. These last strains appeared on the medium 3 days after isolation. The result founded in this study showed that there were among Acacia spp strains both fast and slow-growing strains, they took 3 to 5 days to appear on the YMA medium. All the fast-growing strains have changed the color of YMA+BTB medium from green to yellow while slow-growing strains from green to blue. Among the 77 strains obtained, 30 were not able to grow on GPA+VB while 12 were negative to 3 keto-lactose tests (Figure 1(a)). Only 6 strains were both unable to grow on GPA and were 3 ketolactose negative. These strains were selected for further analysis. The growth curve (Figure 1(b)) of strains showed for most of them that the exponential phase begins after 2 days and the stationary phase after seven days. All strains in this study were Gram-negative (-), Catalase positive $(+)$, and Oxydase positive (+).

\subsection{Secondary Metabolites Production and Beneficial Traits}

To examine the secondary metabolism of strains, urease, pectinase and cellulase activities were tested. All the tested isolates were urease positive (Figure 2(a)), 


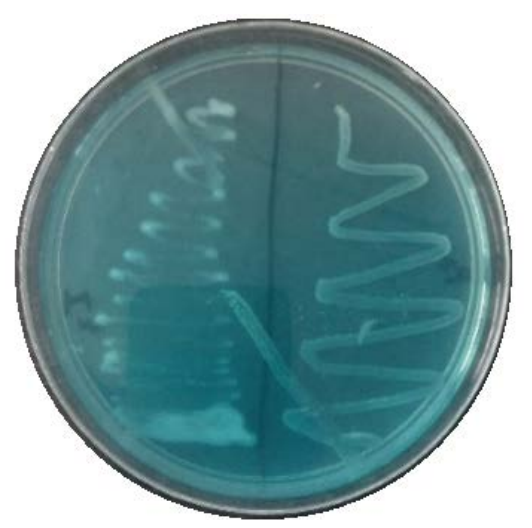

(a)

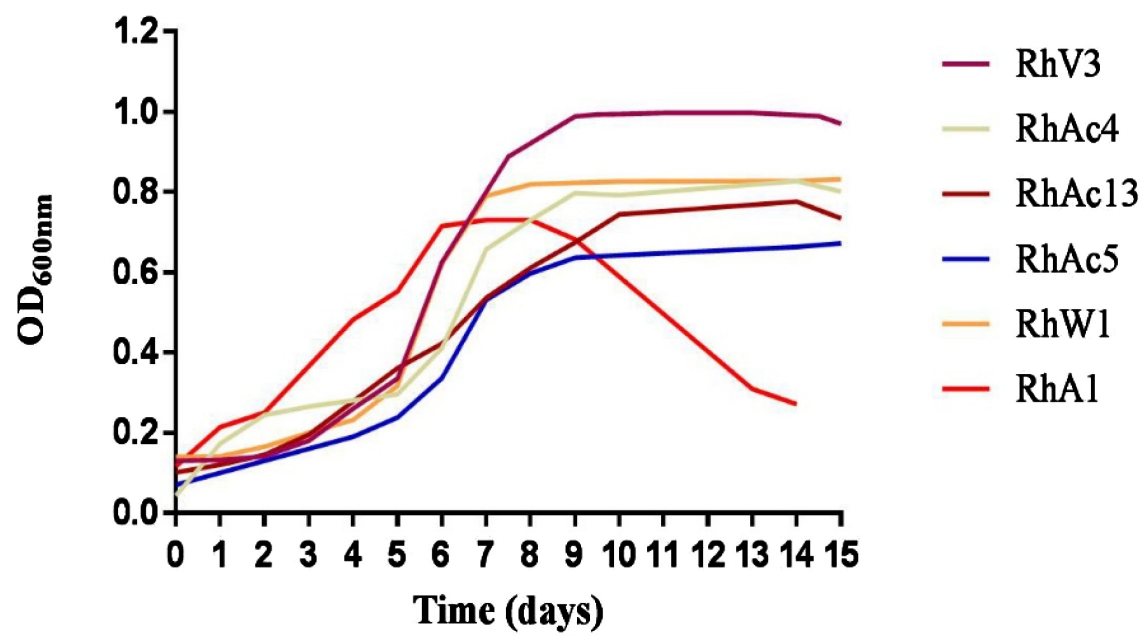

(b)

Figure 1. Agrobacterium-rhizobium tests and growth of native rhizobium. (a) 3-Ketolactose: Absence of a yellow halo around the colonies, the test is negative; (b) Growth curves of native rhizobium.

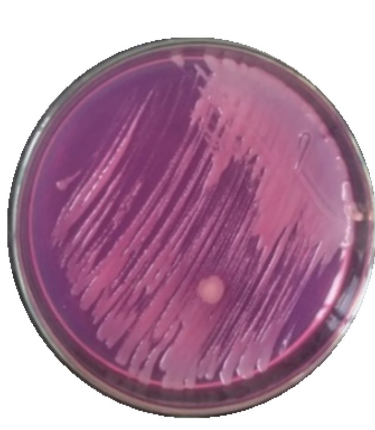

(a)

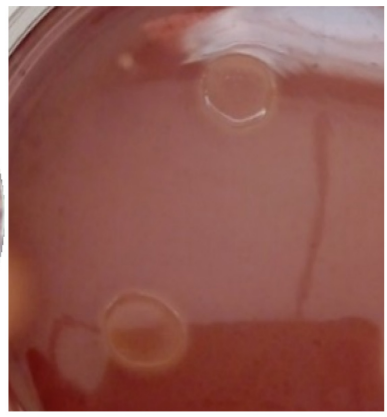

(b)

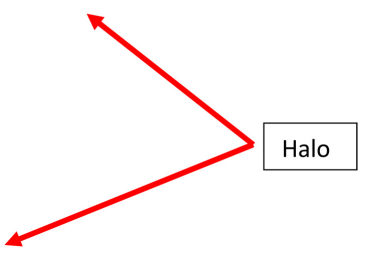

Figure 2. Enzymatic activities of native rhizobium strains. (a) Urease: pink coloring, the test is positive and the yellow coloring testing is negative; (b) Cellulase: Presence of halo, positive test, after 3 days of incubation.

only one strain RhW1 obtained from Milletia laurentii root nodules has shown a positive cellulase activity (Figure 2(b)) the other strains were cellulase negative and no one of them showed a pectinase activity. 


\subsection{Physiological Characteristic of Strains}

The strains have grown on YM medium with different $\mathrm{pH}$. The growth observed was higher on alkaline medium than on acidic medium. The best growth was observed with RhAc13 on neutral pH (Figure 3(a)). Strains growth was better at
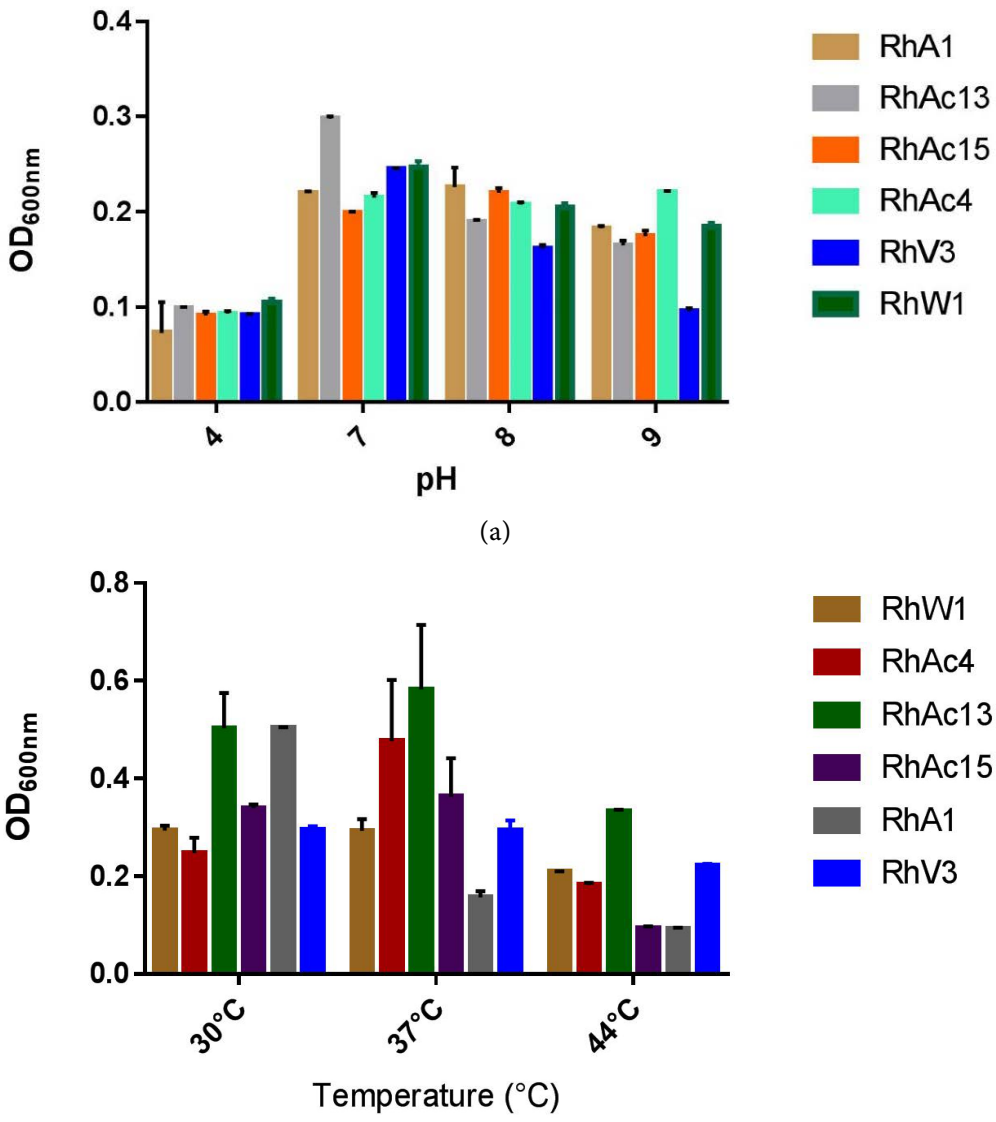

RhW1

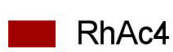

RhAc13

RhAc15

RhA1

RhV3

(b)

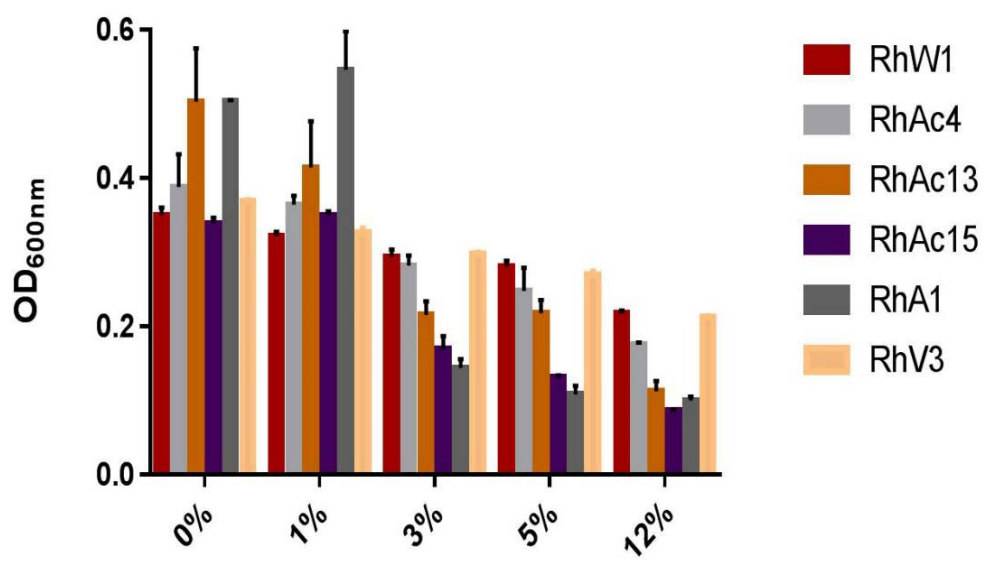

Concentration in $\mathrm{NaCl}$

(c)

Figure 3. Effects of $\mathrm{pH}$, temperature and $\mathrm{NaCl}$ salt on native Rhizobium strains. (a) Effect of pH; (b) Effect of temperature; and (c) Effect of $\mathrm{NaCl}$ on growth of native Rhizobium strains. 
temperatures $30^{\circ} \mathrm{C}$ and $37^{\circ} \mathrm{C}$. The growth decreased at $44^{\circ} \mathrm{C}$. The weakest growth was observed with RhAc15 and RhA1 (Figure 3(b)). The results showed that the growth of RhV3 was not affected by the increase of temperature. The growth of strains decreased as the amount of $\mathrm{NaCl}$ is increased (Figure 3(c)). The best growth was observed at $0 \%$ of $\mathrm{NaCl}$, all native strains were able to grow until $12 \%$ of $\mathrm{NaCl}$. However, the growth was weak at $12 \%$ of $\mathrm{NaCl}$ in the medium. $\mathrm{NaCl}$ seems to have no effect on the growth of RhV3 strain from Vigna unguiculata root nodules because the growth was similar in the range of concentrations used.

\subsection{Carbon Sources Use by Rhizobium Strains}

To detect whether variating carbon sources associated with the growth of strains, ten of them such as mannitol, maltose, arabinose, lactose, galactose, xylose, fructose, saccharose, sorbitol and glucose were tested. The results showed that, all strains were able to use all the carbohydrate tested (Figure 4). RhAc13 showed the greatest activity on the set of carbon sources except with xylose and fructose. The second-best growth was observed with RhA1. For this strain the smallest growth occurs in presence of Arabinose, whereas RhAc4 showed the lowest growth with Sorbitol and Mannitol. In other hand, the weakest growth of RhW1 was noted with maltose and fructose as carbon source. Figure 4 revealed that the lowest growth of RhAc15 was observed in the presence of arabinose.

\subsection{Heavymetals Effectson Native Rhizobium Strains}

The effects of heavy metals were shown in Figure 5(a) and Figure 5(b). This

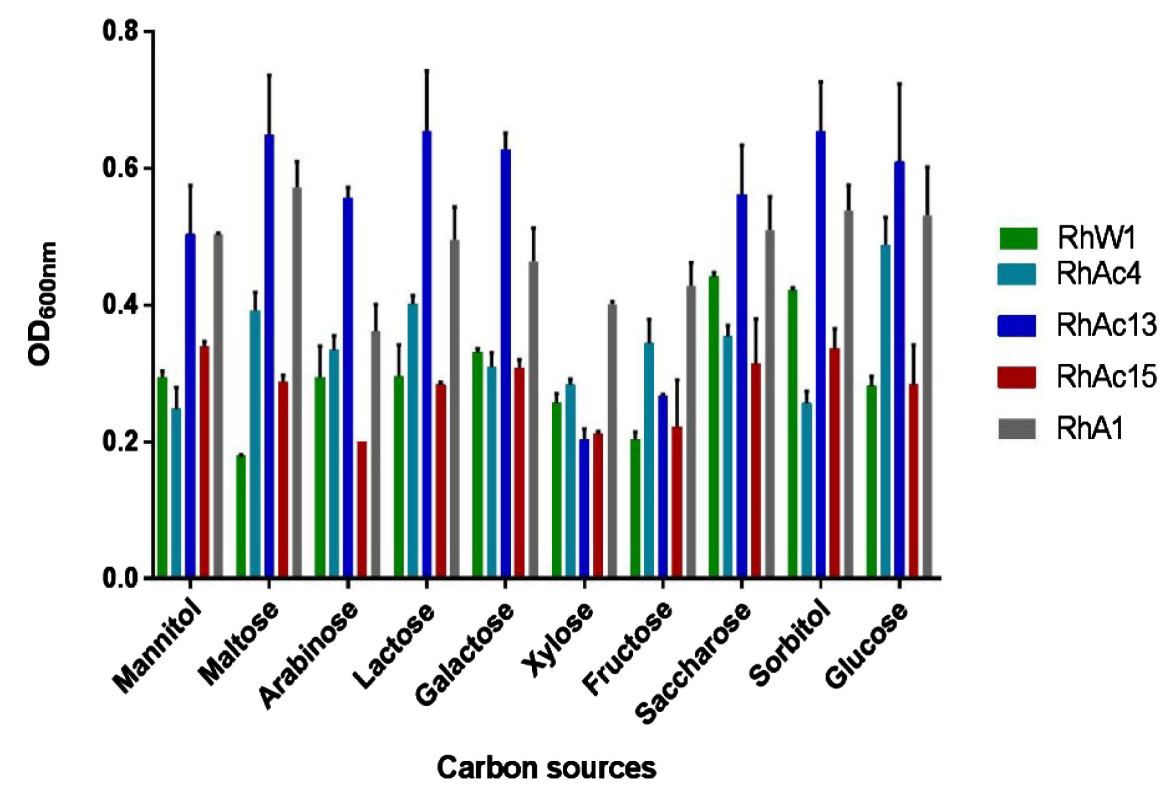

Figure 4. Quantitative estimation of using ten carbon sources by strains in YEM liquid medium. The mannitol was replaced by different carbon sources. Quantitative data of carbon sources in liquid medium were plotted as bar diagrams using mean \pm standard deviation, the ranking of significant variations among isolates using Graph Pad 7.0. 


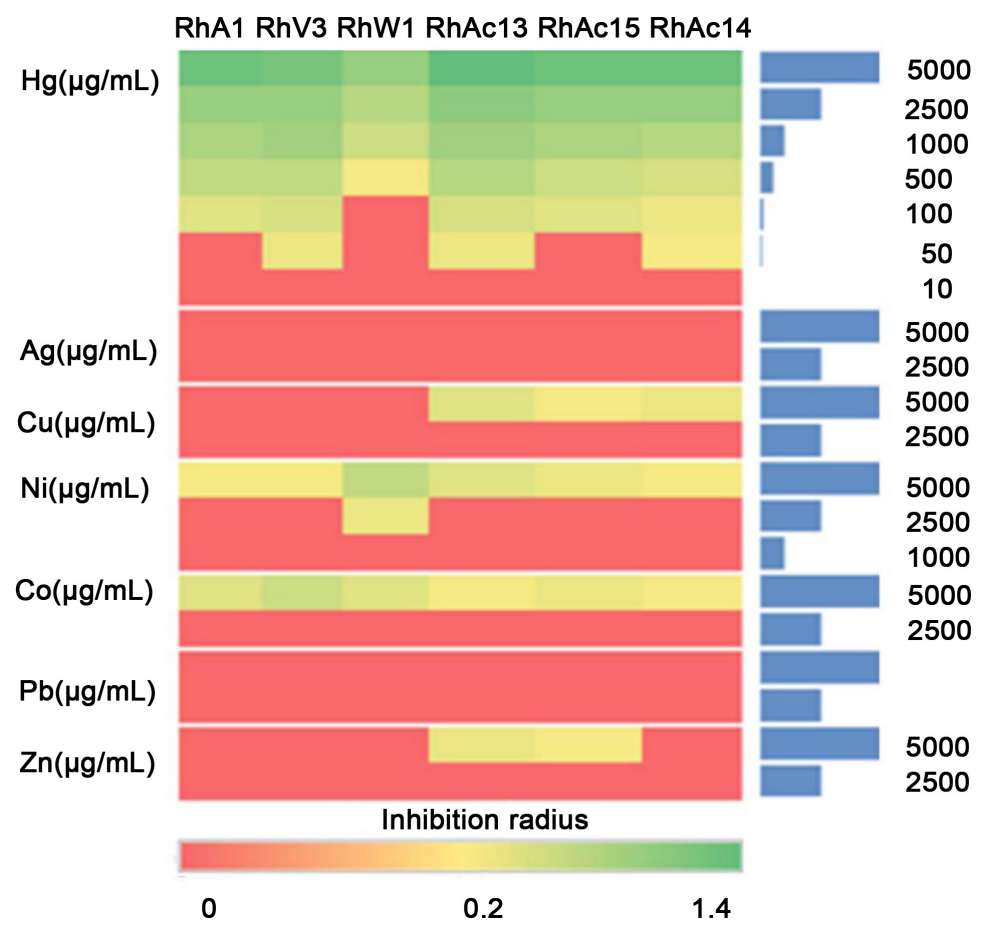

(a)

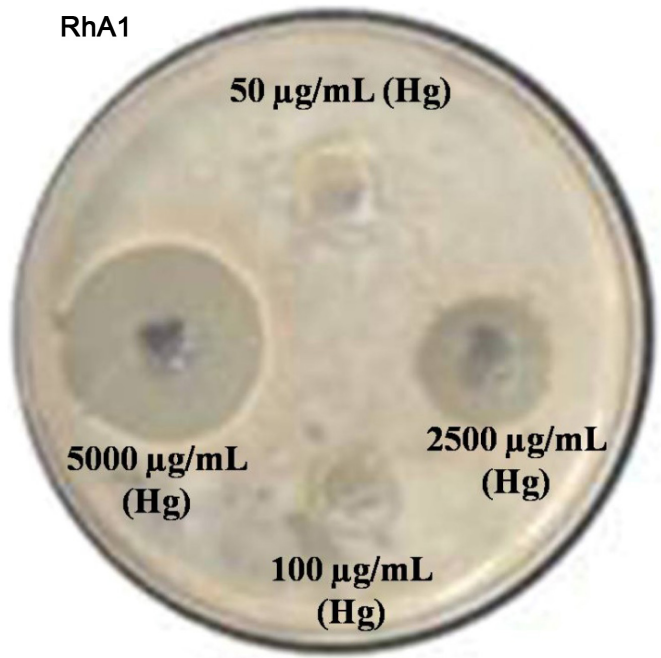

(b)

Figure 5. Heavy metals effects on isolates survival. (a) Heatmaps of differential heavy metals Stress analysis score plot of all inhibition zones from native isolates. (b) Plate showing inhibition zones in centimeter $(\mathrm{cm})$ on different concentrations of $\mathrm{Hg}$.

figure showed that all the strains were resistant to $\mathrm{Ag}, \mathrm{Pb}$ and $\mathrm{Co}$ at $2500 \mu \mathrm{g} / \mathrm{mL}$ (Figure $5(\mathrm{a})$ ). About $50 \%$ of strains tolerated $\mathrm{Hg}$ at $10 \mu \mathrm{g} / \mathrm{mL}, 33.33 \%$ at 50 $\mu \mathrm{g} / \mathrm{mL}$ and $16.66 \%$ at $100 \mu \mathrm{g} / \mathrm{mL}$ (Figure $5(\mathrm{~b})$ ). About $50 \%$ of strains resisted to $\mathrm{CuO}_{2}$ at $5000 \mu \mathrm{g} / \mathrm{mL}$ and the other $50 \%$ resisted at $2500 \mu \mathrm{g} / \mathrm{mL} .83 .33 \%$ of strains resisted to $\mathrm{Ni}$ at $2500 \mu \mathrm{g} / \mathrm{mL}$ while $16.66 \%$ resisted at $1000 \mu \mathrm{g} / \mathrm{ml} .66 .66 \%$ of strains resisted to $\mathrm{Zn}$ at $5000 \mu \mathrm{g} / \mathrm{ml}$ and $33.33 \%$ at $2500 \mu \mathrm{g} / \mathrm{ml}$ (Figure 5 (a) and Figure 5(b)). 


\subsection{Effect of Antibiotics on Native Rhizobium Strains}

The diameter of clear zone around disc varied between 0 and $38 \mathrm{~mm}$. Using the recommendation of European Committee on Antimicrobial Susceptibility Testing, strains tested were classified as sensitive, intermediate and resistant. The strain RhAc13 isolated from Acacia spp. resisted to Ampicillin, Rifampicin, Amoxicillin, Gentamicin, Amikacin, Erythromycin and Oxacillin. It was sensitive to Streptomycin and intermediate to Chloramphenicol (Figure 6(d), Figure 6(f), Figure 6(g), and Figure 6(j)). RhAc15 resisted to all antibiotic except Chloramphenicol for which it was intermediate (Figure 6(d), Figure 6(f), Figure 6(g), Figure 6(h), and Figure $6(\mathrm{j}))$. The result showed that RhAc4 resisted to all the tested

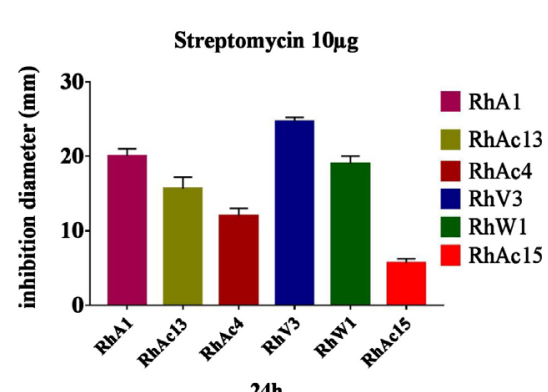

(a)

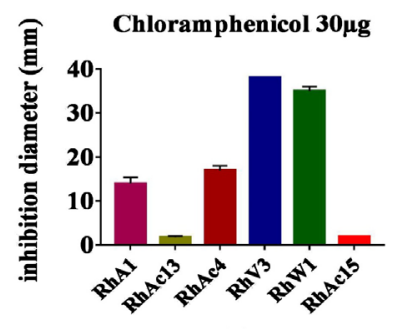

(d)

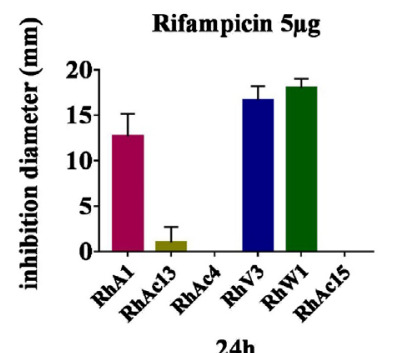

(g)

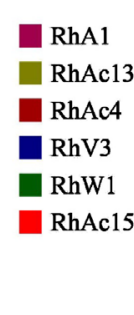

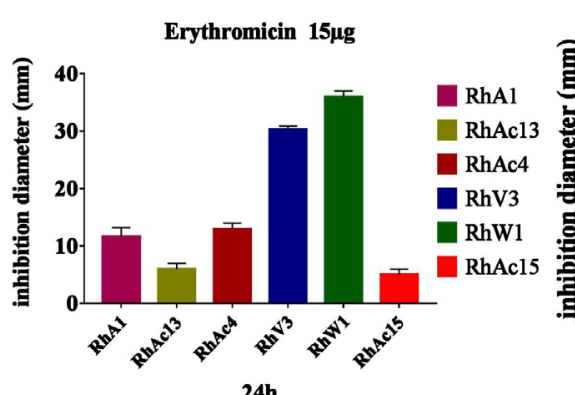

(b)
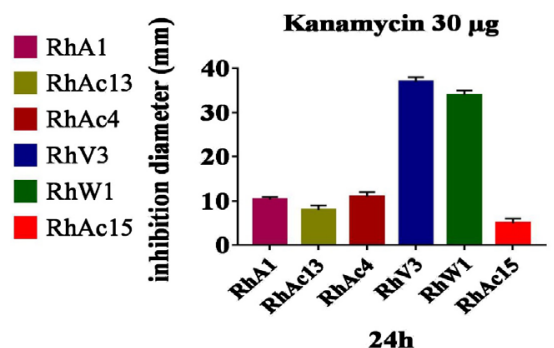

(e)

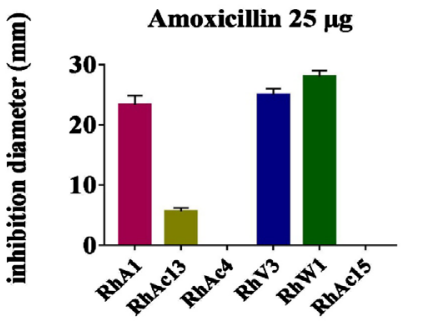

(h)

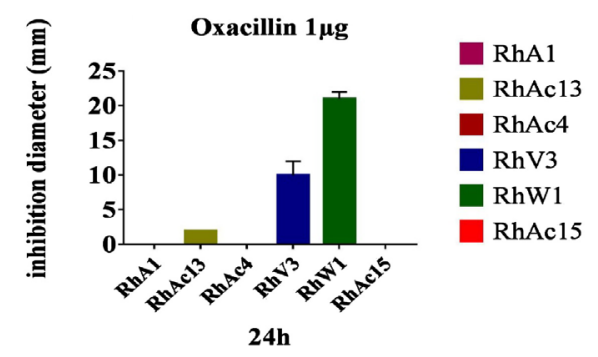

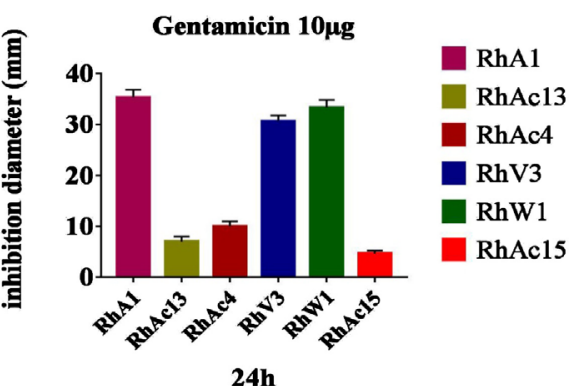

(c)
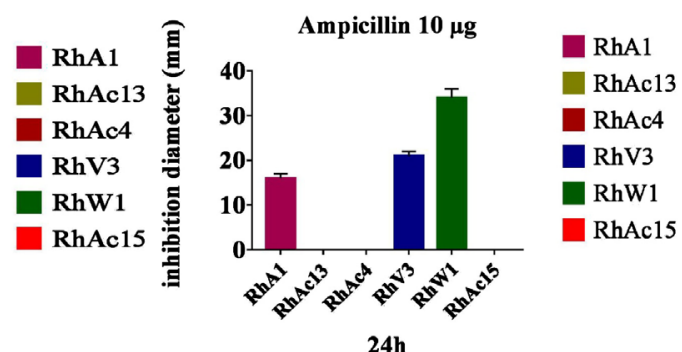

(f)
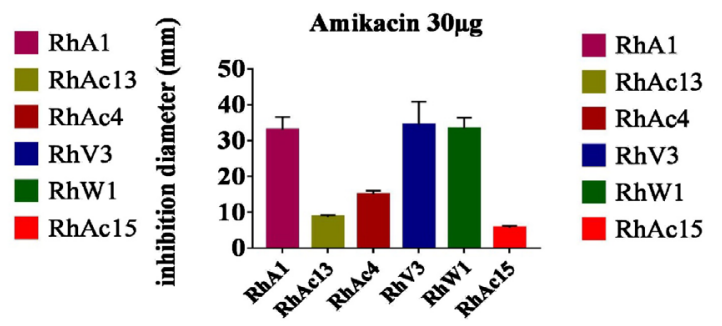

(i)

(j)

Figure 6. Diameter ( $\mathrm{mm}$ ) of inhibition zone according to the tested antibiotic after $24 \mathrm{H}$ of incubation. 
antibiotics (Figure 6(f), Figure 6(g), Figure 6(h), and Figure 6(j)). In other hand the strains RhW1 and RhV3 isolated respectively from Milletia laurentii and Vigna unguiculata were sensitive to all antibiotics except rifampicin for which they were intermediate (Figure 6). RhAl resisted to Oxacillin (Figure 6(j)). Albizia lebeck strain RhA1 was resistant to Erythromycin, Chloramphenicol, Kanamycin and Rifampicin. (Figure 6(b), Figure 6(c), Figure 6(e), Figure 6(i)) but it was sensitive to all others.

\subsection{Molecular Identification of Isolated Bacteria}

Figure 7(a) shows the band sizes above the marker size (M) of electrophoresis

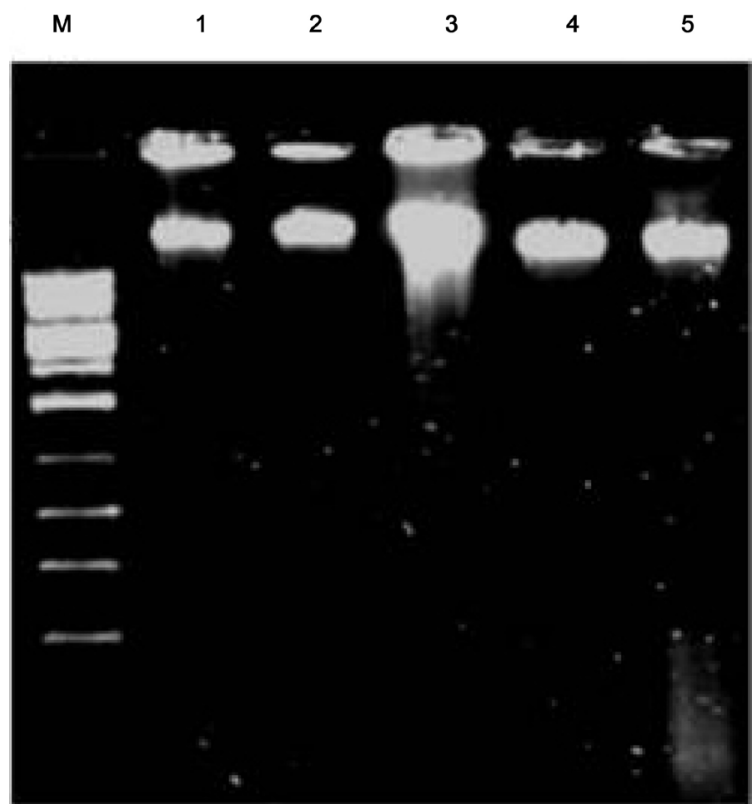

(a)

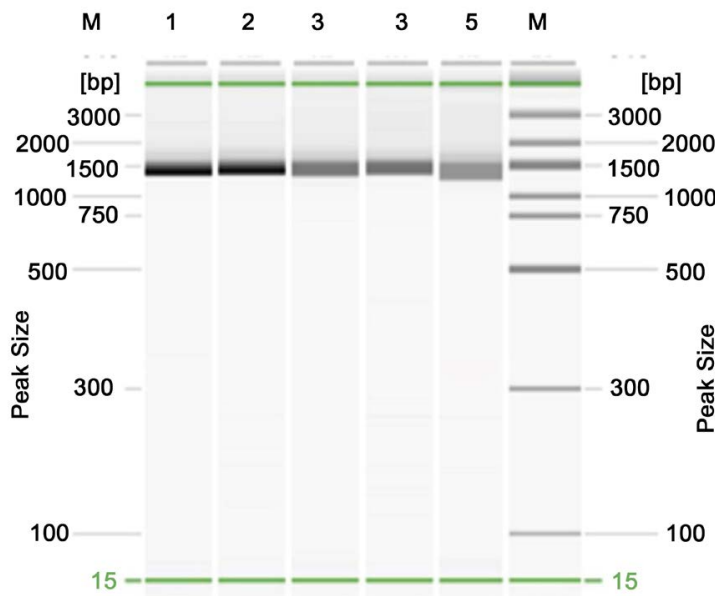

(a)

Figure 7. 16S rRNA expression of native isolates using universal primers. (a) Electrophoresis showing genomic DNA band above marker size; (b) Quality control of 16S rRNA PCR products by Qiaxcel. 
gel of purified genomic DNA extracted from our bacteria strains. The amplification by PCR of 16S rRNA gene using the genomic DNA, revealed by automated capillary electrophoresis (Qiaxcel) showed bands around 1500 bp (Figure 7(b)). The Blastn of all $16 \mathrm{~S}$ genes sequences revealed that strains were related with nitrogen-fixing bacteria, belonging to genera such as Rhizobium, Mesorhzobium, and Bradyrhizobium. The strain isolated from nodule of Vigna unguiculata was characterized as Bradyrhizobium yuanmingense (accession number MT657303) with $99.79 \%$ of homology. The strain isolated from nodule of Milletia laurentii was Bradyrhizobium elkanii (accession number MT657298) with a homology of 99.64\%. The strains isolated from nodule of Acacia were assimilated to Mesorhizobium sp (accession number MT657292), Rhizobim sp. (accession number MT657293) and Rhizobium tropici (accession number MT657291) with respectively $99.72 \%, 99.79 \%$ and $99.86 \%$ of homology. The strain from Albizia lebeck was identified as Rhizobium tropici (accession number MT657288) with an homology of $99.79 \%$ (Table 2).

\subsection{Phylogenetic Tree of the Strains}

The phylogenetic analysis of the nucleotide's sequences related to 16S rRNA using MEGA X software showed a clear diversification of native strains nodulating legumes speciesin the soil of south of Brazzaville (Figure 8(a)). The phylogenetic tree showed that the strains were grouped into four distinct clades classified I to IV (Figure 8(b)). Clade I comprised test strains that clustered with lineages of Rhizobium tropici and Agrobacterium radiobacter in the $16 \mathrm{~S}$ housekeeping gene phylogenies. However, All the strains in Clade II, III, and IV formed a monophyletic group, with very close relatedness to any known type strains for example Mesorhizobium loti MAFF 303099, Bradyrhizobium yuanmingense strain B071 16S.

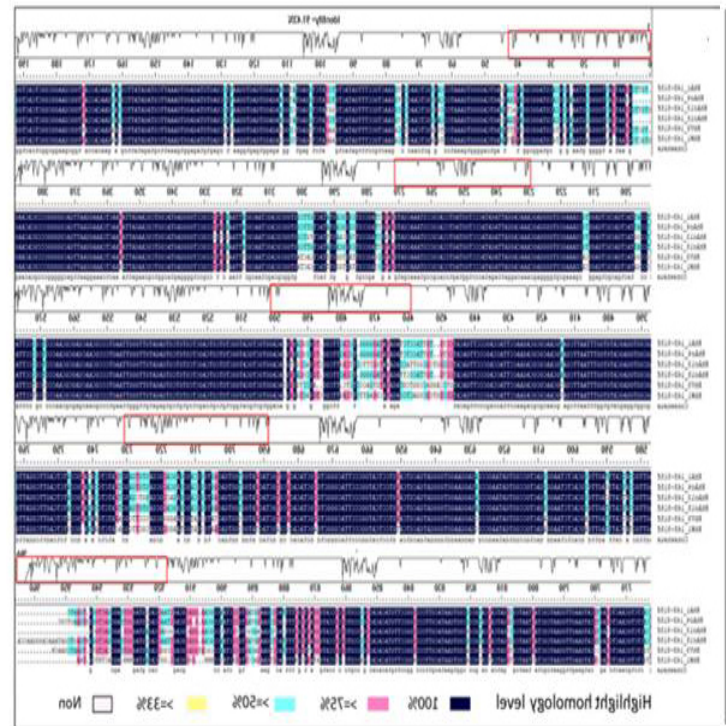

(a)

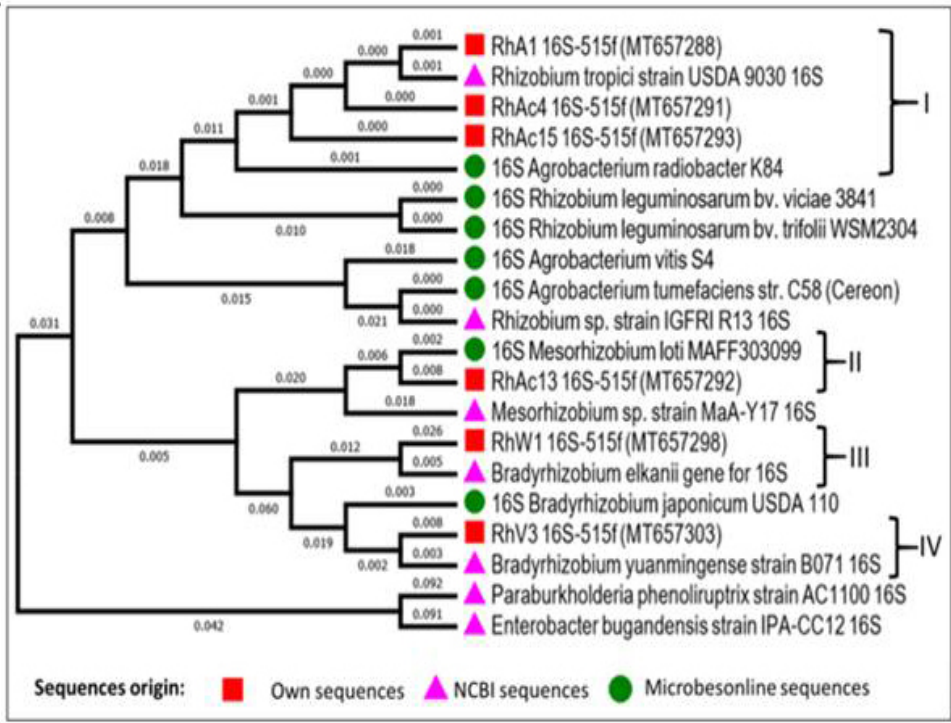

(b)

Figure 8. Molecular phylogeny of $16 \mathrm{~S}$ rRNA in Rhizobium strains. (a) Homology level; (b) Phylogeny tree. 


\section{Discussion}

In this study, strain tested for growth promotional efficacy under different conditions was focused on a native rhizospheric bacterial isolate of legumes species. Microbiota should provide native microorganisms with competitive advantages compared to exotic species with the co-existence for many years with the natural soil [31]. We obtained strains that were white or pink on YEMA RC, translucid or opaque Gram-negative, catalase-positive, and oxidase-positive. The strains were both slow-growing bacteria turning YMA+BTB in bleu and fast-growing bacteria turning YMA+BTB in yellow. Similar characteristics have been demonstrated classifying rhizobia in two groups regarding the apparition time during incubation: fast-growing bacteria for those which appear 3 days maximum after incubation and the slow-growing bacteria which appear after 3 days of incubation [25]. Regarding appearance after incubation, our strains were both slow and fast-growing bacteria; but concerning generation time they were all considerate as slow-growing bacteria.

Rhizobia can produce some enzymes such as urease, amylase, cellulase, pectinase [28]. In the present study, all native strains showed a positive urease activity, negative to cellulase, and pectinase activity except for one strain which shown a positive cellulase activity. Our findings were similar to strains isolated from the root nodule of Dalbergia sissoo concerning urease activity [32]. However, strains associated with root nodule of Hedysarum generashown a negative cellulase activity [33] while a positive cellulase activity with rhizobia isolated from Genista cinerea root nodules [28]. Concerning pectinase activity, our results differed with strains that showed positive pectinase activity [28].

$\mathrm{pH}$, Temperatures and $\mathrm{NaCl}$ are elements that can negatively affect the physiology of bacteria and legume/Rhizobia symbiosis [34] [35] [36]. Several studies have shown that rhizobium strains can grow up to $4 \%$ of $\mathrm{NaCl}$ [32] [37]. However, some rhizobia strains are able to grow at $5 \%$ of $\mathrm{NaCl}$ [38] [39] while some rhizobacteria grew up to $7 \%$ of $\mathrm{NaCl}$ [39]. Some authors showed that rhizobia strains tolerate a wide range of $\mathrm{NaCl}$ below to $12 \%$ [40] [41]. These findings match our results in the fact that the strains obtained in this study were able to grow in a $\mathrm{NaCl}$ medium range from $0 \%-12 \%$. The temperatures effect on strains were similar to those already obtained by others authors [28] [42]. Rhizobia strains can grow up to $40^{\circ} \mathrm{C}$ [32] [37]. Strains obtained in cluster III from chickpea are capable to grow at $42^{\circ} \mathrm{C}$ [38]. Our results are also close to those already reported on slow-growing rhizobia at a temperature above $40^{\circ} \mathrm{C}$ [43]. Slow-growing bacteria are more tolerant to low $\mathrm{pH}$ than fast-growing strains [44], confirmed by Bradyrhizobium and Burkholderia strains that are able to grow at $\mathrm{pH} 3$ [45]. In this study, all the strains had good growth at basic $\mathrm{pH}$ between 7 and 9, and the similar results were obtained with chickpea rhizobia, strains were able to grow at $\mathrm{pH}$ between 5 and 9.5 [38]. In the same way, strains growth at $\mathrm{pH}$ between 5 and 8 respectively from nodule were confirmed [32] [37]. However, rhizobia of Vigna unguiculata L. Walp strains grow at $\mathrm{pH} 10$ 
[46].

Rhizobia strains can grow in the presence of tri and disaccharides, aldoses, and polyalcohol [47]. Some strains also are able to use fructose, glucose, lactose, galactose, and xylose [28]. On the other side, rhizobia strains are not capable to use lactose [32] [37] [48]. Our results corroborate these reports excepted for lactose because our isolates can use lactose.

Some studies have shown that rhizobia strains were resistant to Chloramphenicol, Erythromycin, Kanamycin, Gentamicin, Streptomycin and Rifampicin [48] [49] while others were sensitive to Gentamicin, Kanamycin, Erythromycin, Ampicillin, Streptomycin, Chloramphenicol, Rifampicin and Ampicillin [46] [50]. Our findings showed a resistance with the most of drugs mentioned and also similar to those obtained by [38] with higher concentrations. Several authors reported also that, fast-growing strains are more sensitive to antibiotics than slow-growing strains [44] [51].

Heavy metals adversely influence microorganisms [52] [53]. Toxicity effect created under heavy metals reaction can change native strains by affecting their growth, abundance, genetic diversity, nodulation ability, and efficacy [52]. The growth of some rhizobia strains are inhibited by $\mathrm{CoCl}_{2}(25 \mu \mathrm{g} / \mathrm{ml}), \mathrm{Pb}\left(\mathrm{CH}_{3} \mathrm{COO}\right)_{2}$ $(250 \mu \mathrm{g} / \mathrm{ml})$, but they are insensitive to $\mathrm{HgCl}_{2}(10 \mu \mathrm{g} / \mathrm{ml})$ and $\mathrm{CuCl}_{2}(50 \mu \mathrm{g} / \mathrm{ml})$ [38]. However, rhizobia strains isolated from Vigna Unguiculata resisted to $\mathrm{HgCl}_{2}, \mathrm{CuCl}_{2}, \mathrm{ZnCl}_{2}$ and $\mathrm{Pb}\left(\mathrm{CH}_{3} \mathrm{COO}\right)_{2}$ at low concentrations $(100-200 \mu \mathrm{g} / \mathrm{mL})$ [46]. The results founded in this study are similar to those obtained by [38] only for mercury [38] and totally similar to those obtained by [46]. Tolerance in abiotic factors, resistance to antibiotics, and heavy metals are important features in the selection of strains for biofertilizers [54] [55].

The sequenced 16S RNA gene showed that all the fast-growing strains belonged to Rhizobium genera while the slow-growing were assigned to Mesorhizobium and Bradyrhizobium. Strains obtained from Vigna unguiculata nodules were identified as Bradyrhizobium yuanmingense, Milletia laurentii strains as Bradyrhizobium elkanii; Acacia spp. strains as Mesorhizobium sp., Rhizobium $s p$. and Rhizobium tropici; Albizia lebeck strains as Rhizobium tropici. Most studies reported that Albizia lebeck was nodulated by Bradyrhizobium, Mesorhizobium, and Rhizobium [56] [57]; Acacia by Rhizobium, Mesorhizobium, Bradyrhizobium, and Sinorhizobium [56] [57] [58]. These reports were similar to our finding in the fact that we found Alibizia lebeck nodulated by Rhizobium tropici, Acacia by Rhizobium, and Mesorhizobium. Analyzing the 16S rRNA genes phylogenetically, using a clustering method allowed us to identify four clades among genes with similar patterns, which often indicates that they are active in the same biological processes. The molecular analysis results were consistent with the physiological, morphological, and biochemical traits of the native strains.

\section{Conclusion}

In the present study, 77 isolates were obtained from root nodules of four legu- 
minous: Milletia laurentii, Accacia spp., Albizia lebbeck and Vigna unguiculata. Among these isolates six were picked after Rhizobium-Agrobacterium tests. Them, they were submitted to different biochemical and molecular tests. The main conclusion was that the bacterial community that nodulating the leguminous was greatly diversified. Thereby, the same plant can be nodulated by several kinds of germs. For example, Milletia laurentii was nodulated by a single species Bradyrhizobium elkanii, while the Accacia spp. could be nodulated by Rhizobium tropici, Rhizobium sp. and Mesorhizobium sp. Albizia lebbeck was nodulated by Rhizobium tropici and Vigna unguiculata by Bradyrhizobium yuanmingense. These species could be used to constitute a bank of bacteria nodulating leguiminous. These bacteria could be used in the Congolese agrosystems to improve yield of crops.

\section{Acknowledgements}

Authors thank the head of the Institut national de Recherche en Sciences Exactes et Naturelles who provide partially the finances of this study. We also thank all of the individuals who give their contribution for making up this study.

\section{Conflicts of Interest}

The authors declare that they have no conflict of interests.

\section{References}

[1] Nag, P., Shriti, S. and Das, S. (2020) Microbiological Strategies for Enhancing Biological Nitrogen Fixation in Nonlegumes. Journal of Applied Microbiology, 129, 186-198. https://doi.org/10.1111/jam.14557

[2] Angus, A.A. and Hirsch, A.M. (2010) Insights into the History of the Legume-Betaproteobacterial Symbiosis. Molecular Ecology, 19, 28-30. https://doi.org/10.1111/j.1365-294X.2009.04459.x

[3] Roy, P., Achom, M., Wilkinson, H., Lagunas, B. and Gifford, M.L. (2020) Symbiotic Outcome Modified by the Diversification from 7 to over 700 Nodule-Specific Cysteine-Rich Peptides. Genes (Basel), 11, 348.

https://doi.org/10.3390/genes11040348

[4] Chen, L., Lu, Q., Zhou, L., Li, I., Chen, Z., Sun, L., Wang, W., Lin, Z., Zhao, J., Yamaji, N., Ma, J.F., Gu, M., Xu, G. and Liao, H. (2019) A Nodule-Localized Phosphate Transporter GmPT7 Plays an Important Role in Enhancing Symbiotic N2 Fixation and Yield in Soybean. New Phytologist, 221, 2013-2025. https://doi.org/10.1111/nph.15541

[5] Mohan Jain, S. and Suprasanna, P. (2011) Induced Mutations for Enhancing Nutrition and Food Production. Gene Conserve, 10, 201-215.

[6] Reddy, C.A. and Saravanan, R.S. (2013) Polymicrobial Multi-Functional Approach for Enhancement of Crop Productivity. Advances in Applied Microbiology, 82, 53-113. https://doi.org/10.1016/B978-0-12-407679-2.00003-X

[7] Ren, B., Wang, X., Duan, J. and Ma, J. (2019) Rhizobial tRNA-Derived Small RNAs Are Signal Molecules Regulating Plant Nodulation. Science, 365, 919-922. https://doi.org/10.1126/science.aav8907

[8] Afkhami, M.E., Mahler, D.L., Burns, J. H., Weber, M.G., Wojciechowski, M.F., 
Sprent, J. and Strauss, S.Y. (2018) Symbioses with Nitrogen-Fixing Bacteria: Nodulation and Phylogenetic Data across Legume Genera. Ecology, 99, 502. https://doi.org/10.1002/ecy.2110

[9] Carter, A.M. and Tegeder, M. (2016) Increasing Nitrogen Fixation and Seed Development in Soybean Requires Complex Adjustments of Nodule Nitrogen Metabolism and Partitioning Processes. Current Biology, 26, 2044-2051.

https://doi.org/10.1016/j.cub.2016.06.003

[10] Forrester, N.J. and Ashman, T.L. (2018) The Direct Effects of Plant Polyploidy on the Legume-Rhizobia Mutualism. Annals of Botany, 121, 209-220. https://doi.org/10.1093/aob/mcx121

[11] Sathya, A., Vijayabharathi, R. and Gopalakrishnan, S. (2017) Plant Growth-Promoting Actinobacteria: A New Strategy for Enhancing Sustainable Production and Protection of Grain Legumes. 3 Biotech, 7, 102.

https://doi.org/10.1007/s13205-017-0736-3

[12] Boudehouche, W., Parker, M.A. and Boulila, F. (2020) Relationships of Bradyrhizobium Strains Nodulating Three Algerian Genista Species. Systematic and Applied Microbiology, 43, Article ID: 126074.

https://doi.org/10.1016/j.syapm.2020.126074

[13] Ferraz Helene, L.C., O’Hara, G. and Hungria, M. (2020) Characterization of Bradyrhizobium Strains Indigenous to Western Australia and South Africa Indicates Remarkable Genetic Diversity and Reveals Putative New Species. Systematic and Applied Microbiology, 43, Article ID: 126053. https://doi.org/10.1016/j.syapm.2020.126053

[14] Gritli, T., Ellouze, W., Chihaoui, S.-A., Barhoumi, F., Mhamdi, R. and Mnasri, B. (2020) Genotypic and Symbiotic Diversity of Native Rhizobia Nodulating Red Pea (Lathyrus cicera L.) in Tunisia. Systematic and Applied Microbiology, 43, Article ID: 126049. https://doi.org/10.1016/j.syapm.2019.126049

[15] Beukes, C.W., Boschoff, F.S., Phalane, F.L., Hassen, A.I., le Roux, M.M., Stepkowski, T., Venter, S.N. and Steenkamp, E.T. (2019) Both Alpha- and Beta-Rhizobia Occupy the Root Nodules of Vachellia Karroo in South Africa. Frontiers in Microbiology, 10, 1195. https://doi.org/10.3389/fmicb.2019.01195

[16] Mwenda, G.M., Karanja, N.K., Boga, H., Kahindi, J.H.P., Muigai, A. and Odee, D. (2010) Abundance and Diversity of Legume Nodulating Rhizobia in Soils of Embu District, Kenya. Tropical and Subtropical Agroecosystems, 13, 1-10.

[17] Ohyama, T. (2017) The Role of Legume-Rhizobium Symbiosis in Sustainable Agriculture. In: Legume Nitrogen Fixation in Soils with Low Phosphorus Availability, Springer, Berlin, 1-20. https://doi.org/10.1007/978-3-319-55729-8_1

[18] Mandimba, G.R. and Djondo, Y.M. (1996) Nodulation and Yields of Arachis hypogaea L. as Affected by Soil Management in the Congo. Biological Agriculture \& Horticulture, 12, 339-351. https://doi.org/10.1080/01448765.1996.9754757

[19] Mandimba, G.R. and Mondibaye, A. (1996) Effect of Inoculation and N Fertilization on Soyabean (Glycine max (L.) Merrill) Grown in Congo Soil. Biological Agriculture \& Horticulture, 13, 197-204. https://doi.org/10.1080/01448765.1996.9754781

[20] Mandimba, G.R. (1998) Response of Soyabean Crops to Mucuna pruriens Green Manure in Symbiosis with Cowpea Bradyrhizobia in Congo. Biological Agriculture \& Horticulture, 16, 15-23. https://doi.org/10.1080/01448765.1998.9755215

[21] Lindstrom, K., Murwira, M., Willems, A. and Altier, N. (2010) The Biodiversity of Beneficial Microbe-Host Mutualism: The Case of Rhizobia. Research in Microbiol- 
ogy, 161, 453-463. https://doi.org/10.1016/j.resmic.2010.05.005

[22] Meng, L., Zhang, A., Wang, F., Han, X., Wang, D. and Li, S. (2015) Arbuscular Mycorrhizal Fungi and Rhizobium Facilitate Nitrogen Uptake and Transfer in Soybean/Maize Intercropping System. Frontiers in Plant Science, 6, 339. https://doi.org/10.3389/fpls.2015.00339

[23] Paudel, D., Liu, F., Wang, L., Crook, M., Maya, S., Peng, Z., Kelley, K., Ané, J.-M. and Wang, J. (2020) Isolation, Characterization, and Complete Genome Sequence of a Bradyrhizobium Strain Lb8 From Nodules of Peanut Utilizing Crack Entry Infection. Frontiers in Microbiology, 11, 93.

https://doi.org/10.3389/fmicb.2020.00093

[24] Yuan, K., Reckling, M., Ramirez, M.D.A., Djedidi, S., Fukuhara, I., Ohyama, T., Yokoyama, T., Bellingrath-Kimura, S.D., Halwani, M., Egamberdieva, D. and Ohkama-Ohtsu, N. (2020) Characterization of Rhizobia for the Improvement of Soybean Cultivation at Cold Conditions in Central Europe. Microbes and Environments, 35, 1-13. https://doi.org/10.1264/jsme2.ME19124

[25] Somasegaran, P. and Hoben, H.J. (1985) Methods in Legume-Rhizobium Technology. University of Hawaii, Niftal, 23-77.

[26] Murugesan, S., Manoharan, C., Vijayakumar, R. and Panneerselvam, A. (2010) Isolation and Characterization of Agrobacterium rhizogenes from the Root Nodules of Some Leguminous Plants. International Journal of Microbiology Research, 1, 92-96.

[27] Deshwal, V.K. and Chaubey, A. (2014) Isolation and Characterization of Rhizobium leguminosarum from Root Nodule of Pisum sativum L. Journal of Academia and Industrial Research, 2, 464-467.

[28] Dekak, A., Chabi, R., Menasria, T. and Benhizia, Y. (2018) Phenotypic Characterization of Rhizobia Nodulating Legumes Genista microcephala and Argyrolobium uniflorum Growing under Arid Conditions. Journal of Advanced Research, 14, 35-42. https://doi.org/10.1016/j.jare.2018.06.001

[29] Jarvis, B., MacLean, T.S., Robertson, I.G.C. and Fanning, G.R. (1977) Phenetic Similarity and DNA Base Sequence Homology of Root Nodule Bacteria from New Zealand Native Legumes and Rhizobium Strains from Agricultural Plants. New Zealand Journal of Agricultural Research, 20, 235-248.

https://doi.org/10.1080/00288233.1977.10427328

[30] Kumar, S., Stecher, G. and Tamura, K. (2016) MEGA7: Molecular Evolutionary Genetics Analysis Version 7.0 for Bigger Datasets. Molecular Biology and Evolution, 33, 1870-1874. https://doi.org/10.1093/molbev/msw054

[31] Figueroa-López, A.M., Cordero-Ramírez, J.D., Martínez-Álvarez, J.C., López-Meyer, M., Lizárraga-Sánchez, G.J., Félix-Gastélum, R., Castro-Martínez, C. and Maldonado-Mendoza, I.E. (2016) Rhizospheric Bacteria of Maize with Potential for Biocontrol of Fusarium verticillioides. SpringerPlus, 5, 330.

https://doi.org/10.1186/s40064-016-1780-x

[32] Dhiman, M., Dhiman, V.K., Rana, N. and Dipta, B. (2019) Isolation and Characterization of Rhizobium Associated with Root Nodules of Dalbergia sissoo. International Journal of Current Microbiology and Applied Sciences, 8, 1910-1918. https://doi.org/10.20546/ijcmas.2019.803.227

[33] Yacine, B. (2017) Caractérisation phénotypique et phylogénétique des bactéries associées aux nodules de la légumineuse du genre Hedysarum.

[34] Marandu, A.E., Semu, E., Mrema, J.P. and Nyaki, A.S. (2010) Quantification of Atmospheric N2 Fixed by Cowpea, Pigeonpea and Greengram Grown on Ferralsols in Muheza District, Tanzania. Tanzania Journal of Agricultural Sciences, 10, 29-37. 
[35] Laranjo, M. and Oliveira, S. (2011) Tolerance of Mesorhizobium Type Strains to Different Environmental Stresses. Antonie van Leeuwenhoek, 99, 651-662. https://doi.org/10.1007/s10482-010-9539-9

[36] Dong, R., Zhang, J., Huan, H., Bai, C., Chen, Z. and Liu, G. (2017) High Salt Tolerance of a Bradyrhizobium Strain and Its Promotion of the Growth of Stylosanthes guianensis. International Journal of Molecular Sciences, 18, 1625. https://doi.org/10.3390/ijms18081625

[37] Moghaddam, M.N., Azadeh, H.S., Reza, Z.M. and Amir, L. (2018) Phenotypic and Molecular Characterization of Sinorhizobium meliloti Strains Isolated from the Roots of Medicago sativa in Iran. Biological Journal of Microorganism, 6, 29-39.

[38] Maatallah, J., Berraho, E.B., Muñoz, S., Sanjuan, J. and Lluch, C. (2002) Phenotypic and Molecular Characterization of Chickpea Rhizobia Isolated from Different Areas of Morocco. Journal of Applied Microbiology, 93, 531-540. https://doi.org/10.1046/j.1365-2672.2002.01718.x

[39] Upadhyay, S., Singh, J. and Singh, D. (2011) Exopolysaccharide-Producing Plant Growth-Promoting Rhizobacteria under Salinity Condition. Pedosphere, 21, 214 222. https://doi.org/10.1016/S1002-0160(11)60120-3

[40] Benidire, L., Lahrouni, M., Daoui, K., Fatemi, Z.E.A., Carmona, R.G., Göttfert, M. and Oufdou, K. (2018) Phenotypic and Genetic Diversity of Moroccan rhizobia Isolated from Vicia faba and Study of Genes That Are Likely to Be Involved in Their Osmotolerance. Systematic and Applied Microbiology, 41, 51-61. https://doi.org/10.1016/j.syapm.2017.09.003

[41] Laranjo, M., Alexandre, A. and Oliveira, S. (2017) Global Transcriptional Response to Salt Shock of the Plant Microsymbiont Mesorhizobium loti MAFF303099. Research in Microbiology, 168, 55-63. https://doi.org/10.1016/j.resmic.2016.07.006

[42] M'lakhal, A. (2011) Effet de certains inducteurs de gène nod (composés phénoliques) sur la croissance de Rhizobium en symbiose avec Vicia faba. Caractérisation et lutte biologique. Thèse de Doctorat, Université de Tlemcen, Algérie.

[43] Mohamed, S., Smouni, A., Neyra, M., Kharchaf, D. and Filali-Maltouf, A. (2000) Phenotypic Characteristics of Root-Nodulating Bacteria Isolated from Acacia spp. Grown in Libya. Plant and Soil, 224, 171-183. https://doi.org/10.1023/A:1004838218642

[44] Jordan, D.C. (1984) Rhizobiaceae. In: Krieg, N.R. and Holt, J.G., Eds., Bergey’s Manual of Systematic Bacteriology, Vol. 1, Williams and Wilkins, Baltimore, 234-244.

[45] Ferreira, P.A.A., Dahme, S.F.B., Backes, T., Silveira, A.O., Jacques, R.J.S., Zafar, M., Pauletto, E.A., dos Santos, M.A.O., da Silva, K., Giachini, A.J. and Antoniolli, Z.I. (2018) Isolation, Characterization and Symbiotic Efficiency of Nitrogen-Fixing and Heavy Metal-Tolerant Bacteria from a Coalmine Wasteland. Revista Brasileira de Ciência do Solo, 42, e0170171. https://doi.org/10.1590/18069657rbcs20170171

[46] Abdelnaby, M., Elnesairy, N.N.B., Mohamed, S.H. and Alkhayali, Y.A.A. (2015) Symbiotic and Phenotypic Characteristics of Rhizobia Nodulaing Cowpea (Vigna unguiculata L. Walp) Grown in Arid Region of Libya (Fezzan). Journal of Environmental Science and Engineering, 4, 227-239.

https://doi.org/10.17265/2162-5263/2015.05.001

[47] Graham, P. (1964) The Application of Computer Techniques to the Taxonomy of the Root-Nodule Bacteria of Legumes. Microbiology, 35, 511-517. https://doi.org/10.1099/00221287-35-3-511

[48] Nahar, N., Begum, A. and Akhter, H. (2017) Isolation, Identification and Molecular Characterization of Rhizobium Species from Sesbania bispinosa Cultivated in Ban- 
gladesh. African Journal of Agricultural Research, 12, 1874-1880. https://doi.org/10.5897/AJAR2017.12321

[49] Prasuna, M.L. (2014) Characterization of Rhizobium Isolates Associated with Wild Legumes on the Basis of Antibiotic Resistance. Indian Journal of Scientific Research, 4, 22-24.

[50] Mihaylova, S., Genov, N. and Moore, E. (2014) Susceptibility of Environmental Strains of Rhizobium Radiobacter to Antimicrobial Agents. World Applied Sciences Journal, 31, 859-862.

[51] Elkan, G. (1992) Taxonomy of the Rhizobia. Canadian Journal of Microbiology, 38, 446-450. https://doi.org/10.1139/m92-075

[52] Stan, V., Gament, E., Cornea, C.P., Voaideş, C., Duşa, M. and Plopeanu, G. (2011) Effects of Heavy Metal from Polluted Soils on the Rhizobium Diversity. Notulae Botanicae Horti Agrobotanici Cluj-Napoca, 39, 88-95. https://doi.org/10.15835/nbha3916081

[53] Pereira, S.I.A., Lima, A.I.G. and Figueira, E.M.A.P. (2006) Heavy Metal Toxicity in Rhizobium leguminosarum Biovar Viciae Isolated from Soils Subjected to Different Sources of Heavy-Metal Contamination: Effects on Protein Expression. Applied Soil Ecology, 33, 286-293. https://doi.org/10.1016/j.apsoil.2005.10.002

[54] Odoh, C.K. (2017) Plant Growth Promoting Rhizobacteria (PGPR): A Bioprotectant Bioinoculant for Sustainable Agrobiology. A Review. International Journal of Advanced Research in Biological Sciences, 4, 123-142.

https://doi.org/10.22192/ijarbs.2017.04.05.014

[55] Kenneth, O.C., Nwadibe, E.C., Kalu, A.U. and Unah, U.V. (2019) Plant Growth Promoting Rhizobacteria (PGPR, A Novel Agent for Sustainable Food Production). American Journal of Agricultural and Biological Sciences, 14, 35-54. https://doi.org/10.3844/ajabssp.2019.35.54

[56] Wang, F.Q., Wang, E.T., Zhang, Y.F. and Chen, W.X. (2006) Characterization of Rhizobia Isolated from Albizia spp. in Comparison with Microsymbionts of Acacia spp. and Leucaena leucocephala Grown in China. Systematic and Applied Microbiology, 29, 502-517. https://doi.org/10.1016/j.syapm.2005.12.010

[57] Boakye, E.Y., Lawson, I.Y.D. and Danso, S.K.A. (2016) Characterization and Diversity of Rhizobia Nodulating Selected Tree Legumes in Ghana. Symbiosis, 69, 89-99. https://doi.org/10.1007/s13199-016-0383-1

[58] Amrani, S., Noureddine, N.-E., Bhatnagar, T., Argandoña, M., Nieto, J.J. and Vargas C. (2010) Phenotypic and Genotypic Characterization of Rhizobia Associated with Acacia saligna (Labill.) Wendl. in Nurseries from Algeria. Systematic and Applied Microbiology, 33, 44-51. https://doi.org/10.1016/j.syapm.2009.09.003 